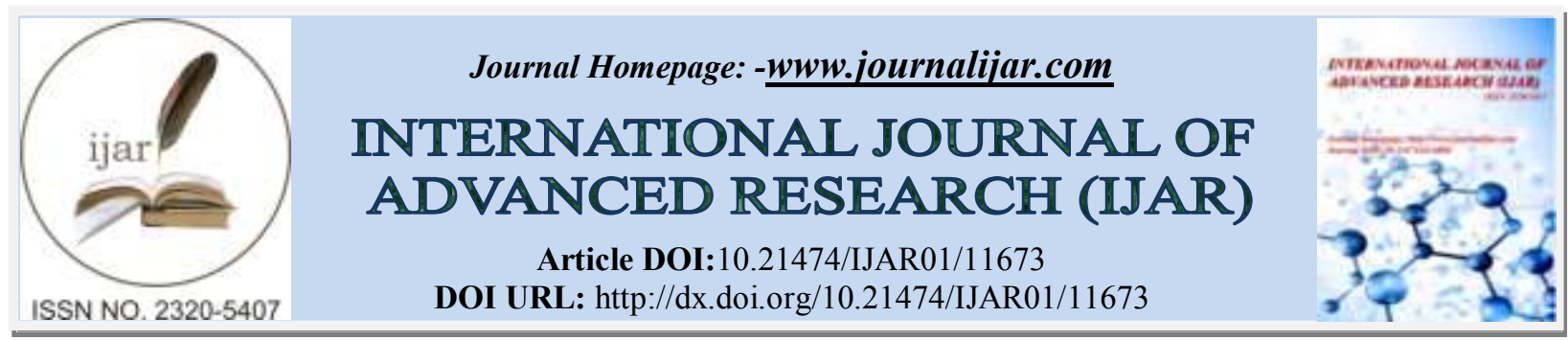

RESEARCH ARTICLE

\title{
USE OF AUDIOVISUAL METHOD IN THE DEVELOPMENT OF ENGLISH- SPEAKING SKILLS OF YOUNG LEARNERS IN UZBEKISTAN
}

\author{
Mukaddaskhon Ogay \\ Head of the multimedia department,Innovation Centre, Uzbek State University of WorldLanguages, Uzbekistan.
}

\begin{abstract}
Manuscript Info
(n........................

Manuscript History

Received: 10 July 2020

Final Accepted: 14 August 2020

Published: September 2020

Key words:-

Audiovisual Method, Young Learner,

Teaching English, Multimedia

Application, Speaking, Listening

Abstract

Teaching a foreign language to primary schoolchildren requires the use of a non-traditional approach in the classroom in order to attract children's interest in the language, as well as to facilitate the educational process. Since learners at this age are not able to go deeply into the grammar rules of using the language being studied, it is necessary to give them the opportunity to hear authentic speech from the very first lessons. Repeated listening to authentic dialogues, watching short videos where native speakers communicate with each other in different situations, using the heardphrases in role-playing games in the classroom contributes to the formation of young learners' listening and speaking skills. The audiovisual method can be an effective tool that will help the teacher organize an interesting and memorable lesson for young learners.
\end{abstract}

Copy Right, IJAR, 2020, All rights reserved.

\section{Introduction:-}

The comprehensive development of relations of the Republic of Uzbekistan with foreign countries in order to strengthen the business, cultural, humanitarian, scientific and other important areas requires an intensive approach to the study of foreign languages, and English, in the first place.

In the conditions of the modern educational space, information and communication technologies in teaching English are good teachers' assistants in teaching young learners. A special place among them is occupied by educational multimedia applications for textbooks with songs, cartoons, video and audio materials for lessons.

The audiovisual method is an effective form of educational activity that not only activates the attention of learners, but also contributes to the improvement of their listening and speaking skills, since the visual support of a foreign language sound system helps understandits meaning more completely and accurately.

Language education in Uzbekistan has undergone significant changes in recent years. According to the requirements of the State Standards, the most careful attention is paid to mastering the skills of speaking and listening, since these skills are the key to successful and full-fledged communication in a foreign language. The formation of communicative competence from the very initial stage of language learning is based on the development of speech (its components) - listening and speaking. Communication in a foreign language is based on the process of successfully developing the skills of understanding, recognition, perception and reproduction of the speech heard. The material used for listening and speaking serves as a model of a real language environment, which allows young learners to be involved in speech practice. 


\section{Audiovisual Materials:}

Providea visual representation of the situation, allow to see the articulation, which facilitates the processes of perception and understanding of foreign language speech.

Listening is a complex receptive, mental-imaginary activity associated with the perception, understanding and processing of information contained in an oral speech communication [3, p. 161].

\section{On the history of the emergence of the audiovisual method}

This method was developed in France in the 50s. of the XX century by the joint efforts of French and Yugoslav scientists. The method was intended for intensive teaching of spoken French to adult learners.

The authors of this method were P. Gberina, P. Revenk, J. Gugeneim, R. Renard. The authors of this method believed that learning a foreign language is necessary in the form of live communication. The basis of the educational process was the creation of situations for communication, so that learning proceeds in an atmosphere of natural speech, stimulating the assimilation of sounds, rhythm of speech. The use of audiovisual resources in the course of language teaching made it possible to develop communication skills with the combination of linguistic and paralinguistic elements [4, p.163].

\section{Application of the audiovisual method in English lessons}

One of the features of this method was the non-use of the native language, especially at the initial stage of training. Interference makes it difficult to develop the skills of oral communication in a foreign language, therefore, it is important to exclude the use of the native language in the lesson.

Video materials allow not only to hear the rise and fall of the voice, pauses between words and sentences, intonation, but also to observe gestures, facial expressions, posture, which contributes to a better understanding and memorization of information by young learners. The regular use of audio and video materials in the classroom helps learners overcome the language barrier.

The introduction of videos, cartoons, as well as colorful animated exercises with dubbing into the educational process changes the nature of the traditional lesson, makes it lively and interesting for children of primary school age, contributes to the enrichment of their language stock and broadening their horizons.

Repeated listening to texts and dialogues allows them to work out the correct pronunciation, develop speaking, and later master the reading and writing techniques.

The introduction of video into the educational process serves as a good incentive to learn an unfamiliar language. "Particularly the use of video has received increasing attention in recentstudies on technology integration into teacher education curricula". [8] When learners realize that they are able to understand a foreign language authentic speech, their self-esteem and motivation to study the subject increase. [10]

The use of the audiovisual method means the introduction of new lexical and grammatical material for listening, and its meaning is revealed with the help of a video series. Language learning takes place by mastering words and phrases using the example of speechheard. In a short period of time, the learner receives a large amount of information through two channels at once: by ear and visually. [6]

The audiovisual education is:

1. oral speech as a basis,

2. dialogue as a teaching structure of colloquial speech,

3. perception of new material through listening,

4. multiple repetition and introduction of an active vocabulary into one's own speech.

This method is especially effective in that the new material is studied through a holistic image, intonation, stress, sounds, rhythm, emotions.

The video is one of the most effective materials in teaching a foreign language. Canning-Wilson finds out in her research that learners enjoy learning a language through videos. [2] 
A clear advantage of the video is the fact that it provides the practice of listening to an authentic language. Films or TV programsare designed for native speakers, so using this kind of video provides authentic language input [5]

For EFLlearners watching a video just once is not enough. 'The first viewingis good for grasping what the learners canand cannot understand, allowing the teacherto give clues for the second viewing. Several comprehension or true/false questions canhelp the learners understand the gist of each scene'. [9]

Advantages and Disadvantages of Using Videos in Lessons

While watching videos, all the learners should be involved into the learning process. The teacher should think about the accompanying activities beforehand. The learners must not be passive, they can work at some projects, take their own speaking, interviewing or reporting videos. [1]

Let's examine the advantages and disadvantages of using videos in foreign language lessons that researchers from different countries offer.

\begin{tabular}{|l|l|}
\hline Advantages & Disadvantages \\
\hline A video can provide authentic language input. & $\begin{array}{l}\text { Not all the teachers are good enough to find the } \\
\text { necessary video material and use it properly in class. }\end{array}$ \\
\hline A video can be used in any classroom environment. & $\begin{array}{l}\text { It can be complicated to find avideo that fully meets the } \\
\text { level of learners' knowledge, and the topic of the lesson. }\end{array}$ \\
\hline $\begin{array}{l}\text { The teacher can easily control the learning process, } \\
\text { using several repetitions if it's necessary. }\end{array}$ & $\begin{array}{l}\text { The quality of a video material can be not perfect. The } \\
\text { poor qualitycan make it difficult to understand it. }\end{array}$ \\
\hline $\begin{array}{l}\text { The process of watching the video can be varied in } \\
\text { speed and sound. }\end{array}$ & $\begin{array}{l}\text { Use of a too long or boring video can lead to lose of } \\
\text { learners' interest }\end{array}$ \\
\hline $\begin{array}{l}\text { A video can help learners to know more about the } \\
\text { culture and communication habits. }\end{array}$ & $\begin{array}{l}\text { It is necessary to remember about the duration of using } \\
\text { the video, so as not to harm the learners' health. }\end{array}$ \\
\hline $\begin{array}{l}\text { It can be easy to catch the main idea of the dialogue/ } \\
\text { conversation observing emotions, gesture, or } \\
\text { environmental details. }\end{array}$ \\
\hline $\begin{array}{l}\text { A video can help teachers attract young learners' interest } \\
\text { to language learning process. }\end{array}$ \\
\hline $\begin{array}{l}\text { As they say, it's better to see once than hear a hundred } \\
\text { times. And it is obvious that a small piece of the video } \\
\text { can replace several sheets of text on a given topic. }\end{array}$ \\
\hline $\begin{array}{l}\text { Both films or educational videos can assist teachers in } \\
\text { presenting the new theme. }\end{array}$ \\
\hline
\end{tabular}

Table 1:- Advantages and disadvantages of using videos.

\section{The activities used with the audiovisual method}

Primary school teachers in Uzbekistan apply the same steps in their lessons as high school teachers.

At the preparatory stage, young learners are taught forecasting, creative thinking and logical deduction of the lesson goal. In the main part of the lesson, they review new material, repeat, learn to ask and answer questions. In consolidating the material, young learners try to apply the new words in practice - in role-playing games they create similar dialogues (sometimes monologues), work in groups on project work and presentations.

Multimedia applications allow the teacher to use effectively the audiovisual method in the classroom to develop listening and speaking skills.

Let's look through some materials offered in the multimedia application to the textbook Kids'English-3 and analyze how songs, videos, interactive activities are used in class with young learners. 


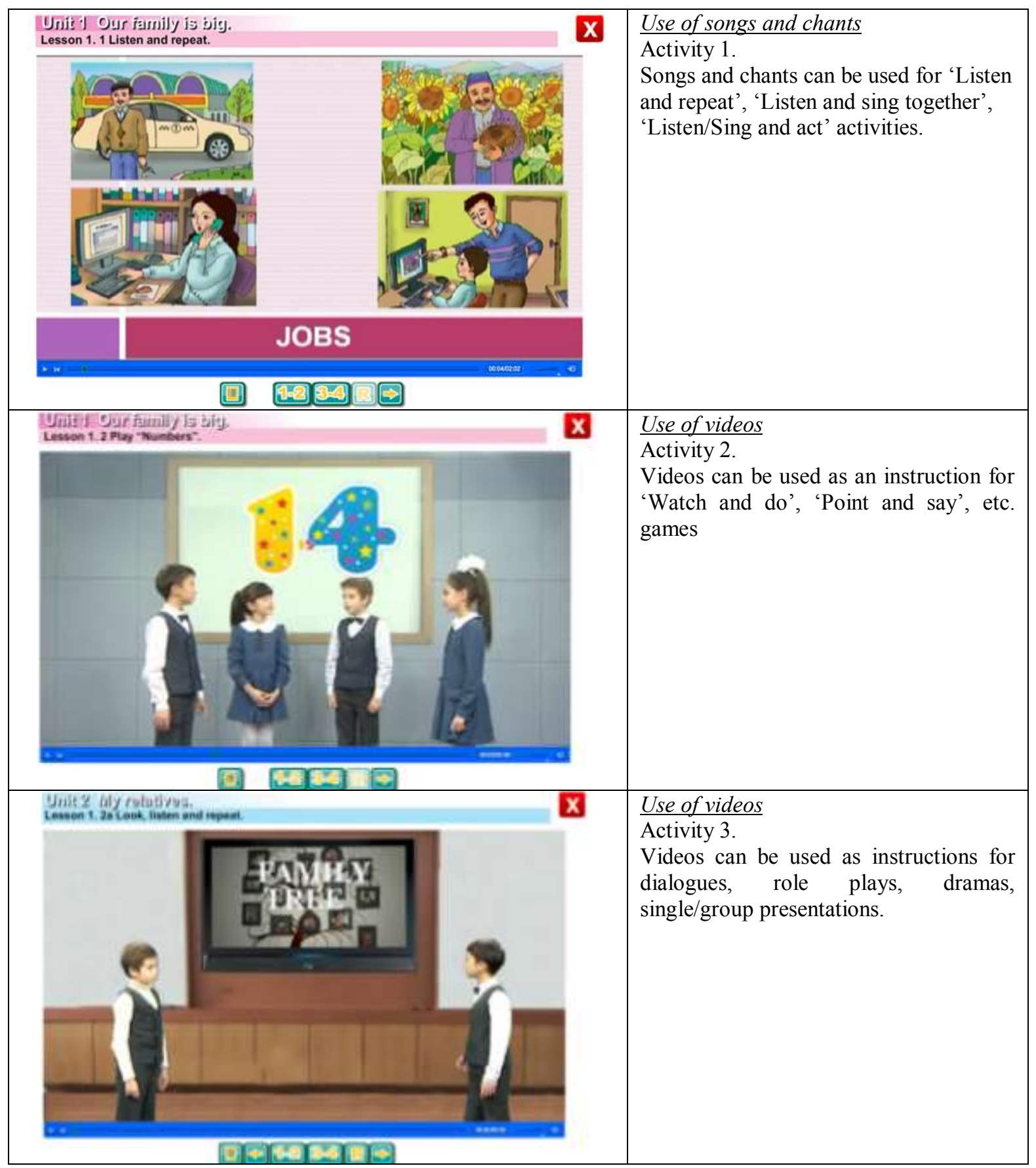




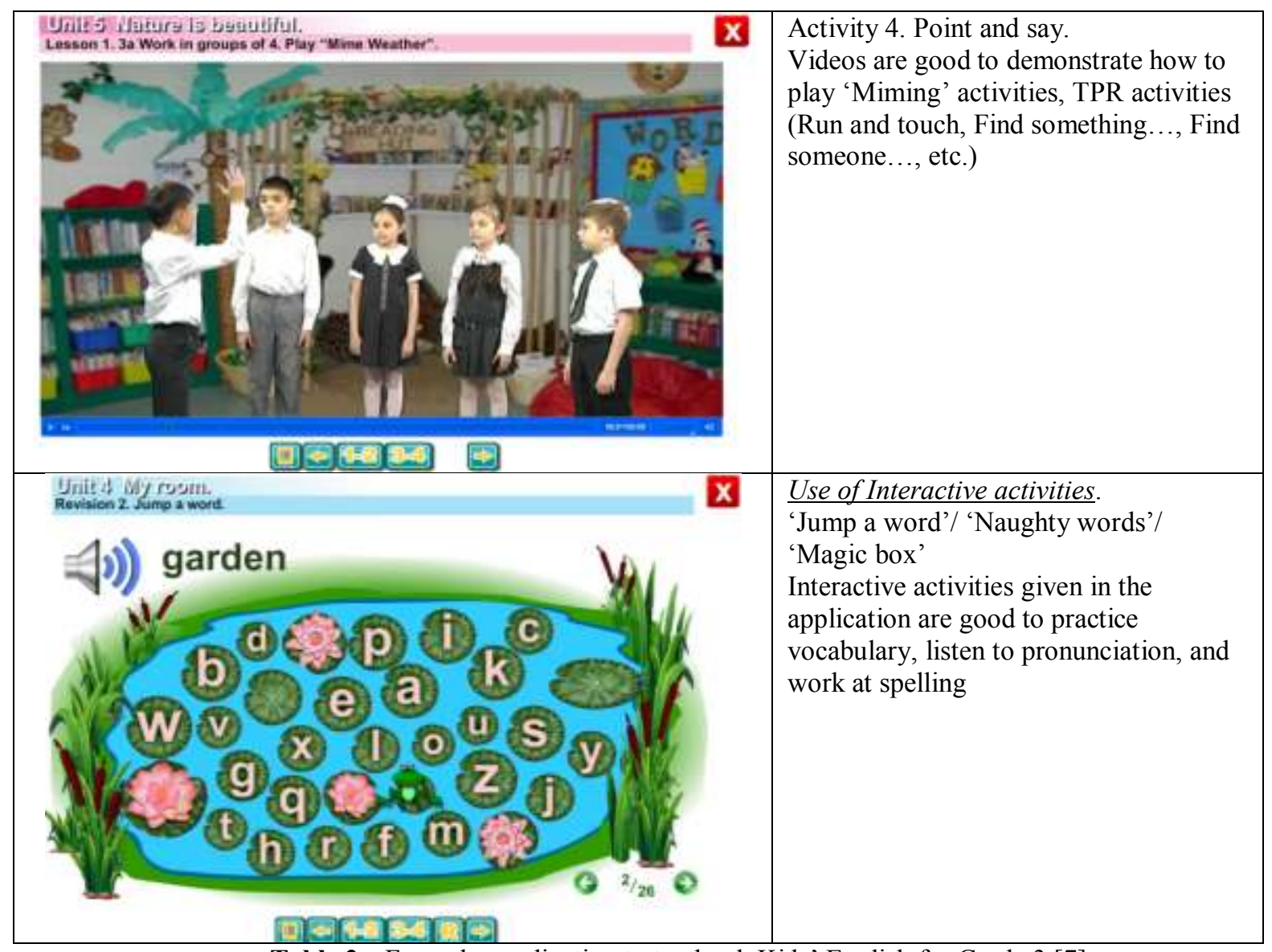

Table 2:- From the application to textbook Kids' English for Grade 3 [7].

As we see the material given in the multimedia application can help teachers organize different types of activities for the development of young learners' speaking skills.

Basic principles of the audiovisual method

Let's look at what principles this method is based on.

\begin{tabular}{|c|c|}
\hline The main in the speech is & -structure, form and content \\
\hline The purpose of the teaching process is & -communicative competence \\
\hline Use of dialogues is based on & $\begin{array}{l}\text {-understanding the structure of phrases, their } \\
\text { meaning and role in the dialogue }\end{array}$ \\
\hline The language is & -created by learners, often by mistakes and errors \\
\hline Learners communicate with & -each other \\
\hline The important things to achieve are & $\begin{array}{l}\text {-fluency of oral speech, correct phonetic design and } \\
\text { situational awareness }\end{array}$ \\
\hline Language learning is & $\begin{array}{l}\text {-the study of sounds, words, grammar structures, as } \\
\text { well as the assimilation of non-verbal } \\
\text { communicationof native speakers. }\end{array}$ \\
\hline Learners know the new vocabulary & -through the context \\
\hline The communication in L2 begins & -from the first steps of learning the language \\
\hline $\begin{array}{l}\text { Use of L1 / Translation from L2 into L1 or from L1 } \\
\text { into L2 }\end{array}$ & -It is practically not used \\
\hline The teacher's role is & $\begin{array}{l}\text {-to present various videos, help learners, and } \\
\text { stimulate their language learning }\end{array}$ \\
\hline
\end{tabular}

Table 3:-Basic principles of the audiovisual method. Advantages and disadvantages of the audiovisual method from the perspective of communicative competence 
As mentioned earlier, the formation of communicative competence is a paramount task in teaching a foreign language. Let's consider the effectiveness of this method for the formation of communicative competence.

The audiovisual method, like other methods, has its advantages and disadvantages.

Among the advantages are the following:

1. The use of the native language in foreign language lessons is excluded as much as possible. The teacher tries to find a video series that match the vocabulary of the learners,

2. the audiovisual method is effective in teaching languages in primary school, since, according to the requirements of the State Standards, primary schoolchildren should, first of all, develop listening and speaking skills,

3. application of this method contributes to immersion in an authentic environment. The use of English children's songs and cartoons in lessons, for example, increases the interest and motivation of learners to learn the language,

4. when working with the audiovisual method, the situation and context are of great importance,

5. the method is accompanied by various forms of activities,

6. the use of video contributes to the study and memorization of speech behavior.

7. The disadvantages include the following:

8. This method does not provide for an in-depth study of the structure of the language, which, according to some teachers, does not contribute to a deep knowledge of the grammar of target language.

\section{Conclusion:-}

To have an effective lesson a teacher does not have to use hightechnologyand expensive materials. 'One of the easiest and least expensive ways for teachers to prepare the most effective teachingmaterials is to look around and never underestimate their sense of creativity'. [11, p.15]

The author believes that the audiovisual method in combination with role-playing games, TPRactivities helps to maintain interest and motivation in learning the language of young learners. At the same time, videos, cartoons, animation tasks must clearly correspond to the objectives of the lesson and the level of knowledge of young learners. The use of a foreign language in the modern world also requires innovative approaches to language teaching.

Today, methods are being integrated into each other in teaching foreign languages. This means that the best elements of the various methods are being searched for to create the most effective integrated method. The author of this article agrees with this approach to teaching, since no method is used in its pure form in English lessons. And each teacher has the right to choose the best methods, according to the age of their learners, their language level, and which meet their interests and needs.

\section{References:-}

1. Çakir, İ. (2006). The use of video as an audio-visual material in foreign language teaching classroom. The Turkish Online Journal of Educational Technology. TOJET. ISSN: 1303-6521. Vol. 5 (4). pp.67-72

2. Canning-Wilson, C. \& Wallace, J. (2000). Practical Aspects of Using Video in the Foreign Language Classroom. The Internet TESL Journal. Vol. VI (11)

3. Galskova, N. (2007). Theory of teaching foreign languages. N. Galskova, N. Gez. 4th ed., Stereotyped. Moscow. Academy. 336 p.

4. Gez, N. (2008). History of foreign methods of teaching foreign languages. N. Gez, G. Frolova. Moscow. Academy. 254 p.

5. Katchen, J.E. (1996). Using authentic video in English language teaching: Tips for Taiwan's teachers. Taipei: The Crane Publishing Company. Ltd Video in ELT-Theoretical and Pedagogical Foundations. Proceedings. (2002) KATE (The Korea Association of Teachers of English) International Conference. pp. 256-259

6. Noskova, T. (2004). Audiovisual technologies in education. T. Noskova. Saint Petersburg. SPbGUKiT

7. Multimedia app to the Kids' English-3. Tashkent. 2015

8. Özkan, B. (2002). The Use of Video Cases in Teacher Education. TOJET. ISSN 1303-6521. Vol.1(1)

9. Rucynski, J. (2011). Using "The Simpsons" in EFL Classes. English Teaching Forum. pp.8-16

10. Vostrikov, A.A., Itsenko, I.A. (2007). English Intensive Course. Immersion method. 1st stage. Tutorial. TomskOdessa. $250 \mathrm{p}$.

11. Yassaei, Sh. (2012). Using Original Video and Sound Effects to Teach English. / English Teaching Forum. United Kingdom. Vol.1. pp.12-16. 